\title{
Day Times Micromole Per Liter Per Milligram Per Gram Per Day
}

National Cancer Institute

\section{Source}

National Cancer Institute. Day Times Micromole Per Liter Per Milligram Per Gram Per

Day. NCl Thesaurus. Code C117915.

Day times micromole per liter, divided by milligram per gram per day. 